\title{
Rancang Bangun Pemantauan Absensi Mahasiswa dengan Menggunakan Sidik Wajah secara Simultan Melalui CCTV Ruang Kelas
}

\author{
Saeful Bahri ${ }^{1}$, Heri Kusindaryadi ${ }^{2}$ \\ ${ }^{1,2)}$ Teknik Elektro Universitas Muhammadiyah Jakarta \\ Jalan Cempaka Putih Tengah 27 No. 47 \\ Email : ${ }^{1)}$ saefulb@ftumj.ac.id , 2) 2015420026@ftumj.ac.id
}

\begin{abstract}
ABSTRAK
Proses absensi yang dilakukan secara manual dinilai kurang efektif karena terbukanya kesempatan melakukan kecurangan. Selain itu, proses rekapitulasi manual membutuhkan waktu yang lama. Sistem absensi dengan teknologi dapat diterapkan untuk membantu proses absensi dan rekapitulasi yang efektif. Pada penelitian ini, teknologi yang digunakan adalah sistem pengenalan wajah. Perancangan sistem pemantauan absensi dengan pengenalan wajah ini menggunakan metode HOG untuk melakukan proses pengenalan wajah. Sedangkan data-data yang dibutuhkan sistem adalah nim, nama mahasiswa, dan dataset foto wajah yang disimpan dalam sistem manajemen relasional basis data. Hasil dari sistem yang dibangun yaitu dapat memantau absensi mahasiswa dengan efektif, serta melakukan perekapan data absensi. Proses absensi mahasiswa berhasil dilakukan pada kondisi pencahayaan dan jarak objek dengan kamera harus sesuai dengan standar uji coba.
\end{abstract}

Kata kunci : pemantauan, absensi, face recognititon, histogram of oriented gradient, raspberry, kamera

\begin{abstract}
The attendance process that is done manually is considered less effective because of the opening opportunities for cheating. In addition, the manual recapitulation process takes a long time. The attendance system with technology can be applied to help attendance and recapitulation processes effectively. In this study, the technology used is a face recognition system. The design of attendance monitoring system with facial recognition uses the HOG method to perform facial recognition processes. While the data needed by the system is the student's name, student's name, and face photo dataset stored in the relational database management system. The results of the system built are able to effectively monitor student attendance, as well as attendance data recording. The student attendance process was successfully carried out in lighting conditions and the distance of the object to the camera must be in accordance with the test standards.
\end{abstract}

Keywords: monitoring, absenteeism, face recognititon, histogram of oriented gradient, raspberries, camera

\section{PENDAHULUAN}

Manusia memiliki kemampuan untuk mengenal puluhan bahkan ratusan wajah selama hidupnya. Seseorang dapat mengenali wajah orang lain meskipun tidak beberapa waktu lamanya dan sudah terdapat perubahan pada wajah orang yang dikenal tersebut. Perubahan itu misalnya variasi ekspresi wajah, penggunaan kacamata, perubahan warna dan gaya rambut. Salah satu teknik biometric yang sangat menarik adalah aplikasi yang mampu mendeteksi dan mengidentifikasi wajah [1].

Saat ini, pengenalan wajah melalui aplikasi komputer dibutuhkan untuk mengatasi berbagai masalah, antara lain dalam identifikasi pelaku kejahatan, pengembangan sistem keamanan, pemrosesan citra maupun film, dan interaksi manusia komputer. Pengenalan wajah yang merupakan salah satu ciri biometric teah banyak dikembangkan untuk system yang mendukung aspek keamanan.

Pada bidang keamanan penggunaan kamera direalisasikan sebagai sensor visual guna mengindentifikasi adanya kejahatan. Pada saat ini kamera yang banyak digunakan adalah jenis CCTV. Hampir disetiap sudut mulai dari fasilitas publik, pusat perbelanjaan, bank, perpustakaan, jalan raya sampai rumah pribadi dilengkapi dengan kamera pengaman. Kamera CCTV ini mampu mengidentifikasi seluruh obyek yang tertangkap oleh kamera ini, dan pada umumnya record data 
RESISTOR (Elektronika Kendali Telekomunikasi Tenaga Listrik Komputer) Vol. 3 No. 1 e-ISSN : 2621-9700, p-ISSN : 2654-2684

menggunakan CCTV dilakukan secara kontiyu berdasarkan waktu record.

Sistem pengenalan wajah (Face Recognition) telah banyak diaplikasikan dengan menggunakan berbagai metode, diantaranya: Metode PCA biasa disebut Analisis Komponen Utama [2], Metode ICA biasa disebut Analisis Komponen Bebas [3], Metode LDA biasa disebut Analisis Diskiminan Linier [4], Metode SVM dapat dijelaskan secara sederhana sebagai usaha mencari hyperplane terbaik yang berfungsi sebagai pemisah dua buah class pada input space [5], Metode HMM sistem yang mencari parameter markov [1], Metode Histogram of Oriented Gradients (HOG) yang diartikan sistem yang memutuskan hasil pendeteksian apakah manusia atau bukan manusia [6]. Adapun kelebihan dari PCA dari segi akurasi dan kompleksitas waktu, namun memiliki kekurangan yaitu membutuhkan banyak koefisien dalam menyimpan data [2]. Pada Metode ICA kekuranganya adalah tidak dapat memproses pengenalan wajah secara real time dan kelebihannya dapat memilah dengan cara mengekstrak ciri [3]. Pada Metode LDA mempunyai Kelebihan Mampu mengoptimalkan antar kelas citra wajah dan akurasi tinggi. Kekurangannya tidak cocok untuk data dengan dimensi tinggi [4]. Pada Metode SVM kelebihannya mampu menemukan hyperplane terbaik yang memisahkan dua buah class pada input space [7]. Pada Metode HMM kelebihannya mampu memodelkan data 2 dimensi seperti citra dengan baik dan membandingkan tingkat akurasi pengenalan wajah, sehingga sulit mendeteksi beberapa wajah yang mirip [1]. Aplikasi sistem pengenalan wajah secara real time dapat ditemukan pada system pengawasan, identifikasi dan keamanan yang berbasis pada pengenalan wajah [8]. Berbagai sistem monitoring presensi yang ada memiliki kekurangan dan kelebihan masing-masing, dan perlu untuk terus dikembangkan sehingga memudahkan dalam proses pengolahan datanya [9]. Pemeliharaan kondisi mesin di industri membutuhkan kecepatan dan kemudahan, salah satu metodenya adalah dengan analisis getaran [10]. Kemampuan manusia dalam mengenali berbagai macam objek, seberapa pun rumitnya objek tersebut, merupakan kemampuan istimewa yang dimiliki manusia [11]. Sepeda motor merupakan kendaraan yang lazim digunakan oleh semua kalangan; mulai dari kalangan atas, menengah, sampai kalangan bawah [12]. Arduino berfungsi membaca nilai pada sensor tegangan AC, sensor tegangan DC, LCD [13]. Perkembangan ilmu pengetahuan teknologi saat ini ditandai dengan bermunculannya alat-alat yang menggunakan sistem kontrol digital dan otomatis [14]. Air menjadi salah satu bahan pokok di masyarakat yang sangat berperan dalam kehidupan [15]. Input dan output adalah hal paling mendasar yang harus diperhatikan dalam membuat sebuah program [16]. Seperti kita ketahui bahwa administrator juga manusia biasa yang mana membutuhkan istirahat dan tidak selalu berada pada tempat kerjanya. [17]. Website adalah keseluruhan halaman-halaman web yang terdapat dalam sebuah domain yang mengandung informasi [18]. Peningkatan citra sidik jari merupakan langkah penting dalam proses preprocessing dalam pengenalan sidik jari aplikasi [19].

Dari beberapa metode diatas, disini akan dicoba mengembangkan Sistem pengenalan wajah (Face Recognition) menggunakan metode HOG, Dimana pada sistem ini kamera digital digunakan untuk proses pengenalan wajah menggunakan metode Histogram of Oriented Gradients (HOG). Proses pengenalan wajah menggunakan metode HOG bertujuan untuk mendeteksi kehadiran manusia didalam suatu area pantauan kamera. Sedangkan proses record data akan dilakukan secara otomatis, yaitu pada saat terdeteksi obyek (manusia) dan proses record data akan berhenti pada saat obyek sudah tidak terdeteksi oleh camera. Proses record data pada aplikasi ini selain dalam bentuk video juga akan merecord jumlah manusia yang terdeteksi oleh kamera tersebut.

Secara umum bahasa pemrograman yang digunakan untuk membangun aplikasi adalah dengan meggunakkan bahasa pemrograman python. Python adalah bahasa pemrograman multiguna dengan filosofi perancangan yang berfokus pada tingkat keterbacaan kode. Phyton diklaim sebagai bahasa yang menggabungkan kapabilitas, kemampuan dengan sintaksis kode yang sangat jelas, dan dilengkapi dengan fungsionalitas pustaka standar dengan sintaksis yang benar serta komperhensif PHP, HTML, Javascript.

Kedepannya diharapkan peneliti ini dapat memberikan manfaat untuk mahasiswa, dosen, dan staf perkuliahan dalam merekap absensi Serta dapat dikembangkan dengan membuat sistem-sistem baru yang memiliki tingkat akurasi tinggi dalam mendeteksi dan mengenali wajah.

\section{TINJAUAN PUSTAKA}

Menurut kamus besar bahasa Indonesia, pengertian wajah atau muka adalah bagian depan dari kepala, pada manusia meliputi wilayah dari dahi hingga dagu, termasuk rambut, dahi, alis, mata, hidung, pipi, mulut, bibir, gigi, kulit, dan dagu [20]. Tidak ada satupun wajah di dunia ini yang serupa 
RESISTOR (Elektronika Kendali Telekomunikasi Tenaga Listrik Komputer) Vol. 3 No. 1 e-ISSN : 2621-9700, p-ISSN : 2654-2684

mutlak, meskipun pada kembar identik sekalipun. Perbedaan seperti halnya berbeda wajah, berbeda sidik jari, berbeda iris mata, berbeda warna kulit, berbeda suara, berbeda bahasa dan sebagainya. Dapat dibayangkan apabila semua manusia memiliki ciri-ciri yang sama. Maka manusia tidak dapat membedakan antara satu dengan yang lainnya. Manusia tidak akan memiliki identitas yang melekat kepada dirinya. Salah satu contoh identitas yang telah disebutkan sebelumnya adalah wajah.

Wajah adalah salah satu dari ciri biometrik pada diri manusia sebagai identitas yang melekat pada orang yang memilikinya. Terdapat elemenelemen penentu terbentuknya wajah seperti bentuk mata, alis, hidung, mulut dan elemen- elemen lain yang semua itu membentuk sebuah pola yang kemudian dinamakan wajah.

Image Processing (pengolahan citra) secara umum juga disebut sebagai digital image processing, merupakan ranah sains yang bersifat multidisiplin karena menerapkan berbagai prinsip dari berbagai bidang sains seperti optik, ilmu komputer, matematika, surface physics dan visal psychiphysics. Beberapa aplikasi image processing meliputi remote sensing, feature extraction, face detection, finger-print detection, optical sorting, argument reality, microscope imaging, lane departure warning system, Non-photorealistic representation, medical image processing, dan morphological imaging.

Wajah merupakan bagian dari tubuh manusia yang menjadi fokus perhatian di dalam interaksi sosial, wajah memainkan peranan vital dengan menunjukan identitas dan emosi. Kemampuan manusia untuk mengetahui seseorang dari wajahnya sangat luar biasa. Kita dapat mengenali ribuan wajah karena frekuensi interaksi yang sangat sering ataupun hanya sekilas bahkan dalam rentang waktu yang sangat lama. Bahkan kita mampu mengenali seseorang walaupun terjadi perubahan pada orang tersebut karena bertambahnya usia atau pemakaian kacamata atau perubahan gaya rambut. Oleh karena itu wajah digunakan sebagai organ dari tubuh manusia yang dijadikan indikasi pengenalan seseorang atau face recognition [1].

\section{PERANCANGAN SISTEM}

Raspberry

PC/Laptop

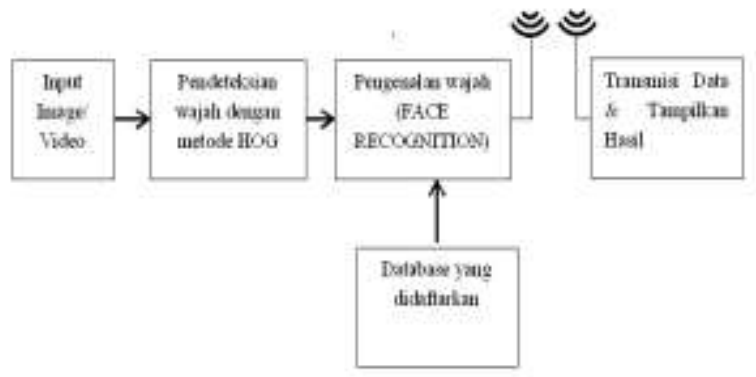

Gambar 1 Blok diagram.

Pada blok diagram diatas dijelaskan langkah kerja yang dilakukan sistem dengan tahap awal input image/ video wajah mahasiswa. Proses capture image di proses oleh raspberry. Selanjutnya raspberry mendeteksi wajah mahasiswa menggunakan metode HOG untuk mengetahui kehadiran mahasiswa tersebut. Kemudian wajah mahasiswa tersebut dikenali oleh sistem pengenalan wajah atau disebut face recognition. Pengenalan wajah mahasiswa selanjutnya dicocokan oleh database yang didaftarkan mahasiswa. Semua proses face recognition dan pencocokan database dilakukan oleh raspberry. Kemudian raspberry mengirimkan data hasil pengenalan wajah dan pencocokan database ke PC/ laptop. Hasil nya muncul di localhost dalam bentuk nim, nama mahasiswa, dan jam masuk. Ketika saat capture image ada wajah mahasiswa yang tidak terdeteksi, PC/laptop akan mengirimkan permintaan ke raspberry untuk mengenali wajah mahasiswa dan pencocokan database kembali. Secara berulang-ulang sistem ini menjalankan face recognition dan pencocokan database sampai terdeteksi wajah mahasiswa yang didaftarkan.

Proses transmisi data dan menjalankan server dilakukan oleh PC/laptop. Rasberry disini memproses dua server yang masing-masing mempunyai tugas yang berbeda.

Yang pertama server PHP dikendalikan oleh Control XAMPP tugasnya untuk menghandle web yang isinya semua halaman MySQL dan PHP. MySQL gunanya untuk menyimpan data mahasiswa yang akan dijadikan objek dan PHP gunanya untuk menjembatani data yang disimpan di My SQL yang disini sebagai database. Database tersebut berisi data mahasiswa seperti nim, nama mahasiswa dan foto mahasiswa yang didaftarkan.

Yang kedua server python gunanya untuk menjalankan face recognition (pengenalan wajah)

1 untuk memasukan data mahasiswa. Wajah muhasiswa yang terdeteksi dikenali oleh sistem face recognition. Data mahasiswa yang disimpan harus segera didaftarkan melalui server python. Dikarenakan saat sistem berjalan wajah mahasiswa 
RESISTOR (Elektronika Kendali Telekomunikasi Tenaga Listrik Komputer) Vol. 3 No. 1 e-ISSN : 2621-9700, p-ISSN : 2654-2684

dapat dikenali dan akan mencari database yang sesuai dengan yang didaftarkan. Selanjutnya hasil akan muncul di localhost berbentuk nama, nim, dan jam masuk.

Untuk lebih lengkapnya dapat dijelaskan langkah-langkah dan alur berjalan sistem ini, sebagai berikut:

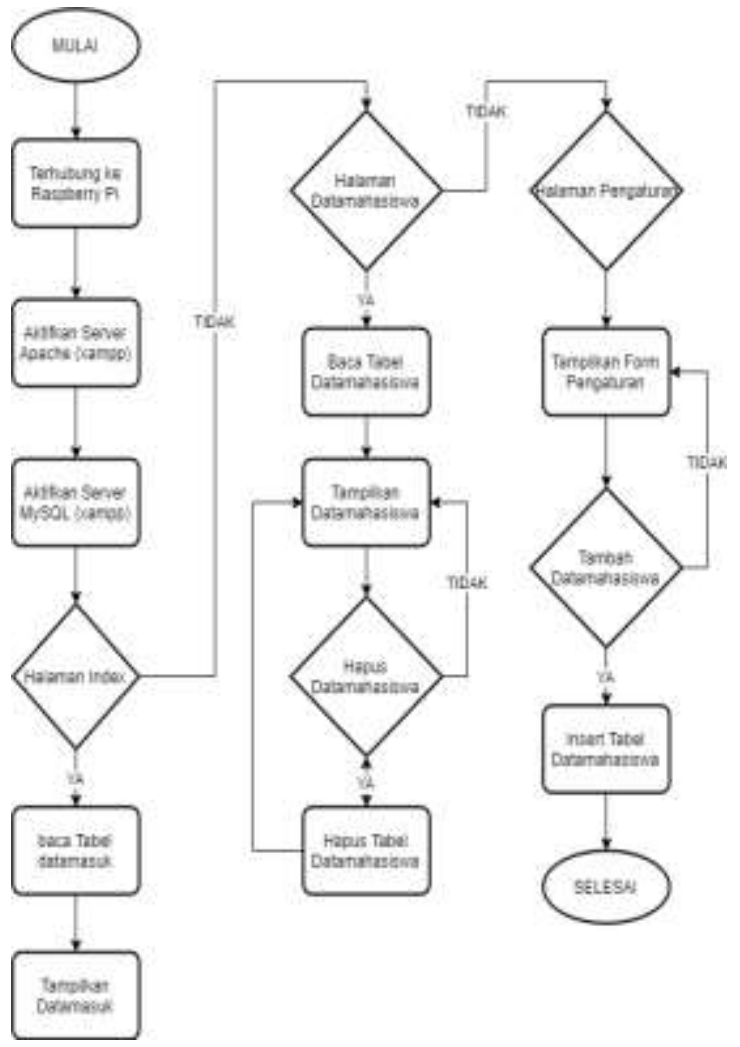

Gambar 2 Alir diagram server PHP.

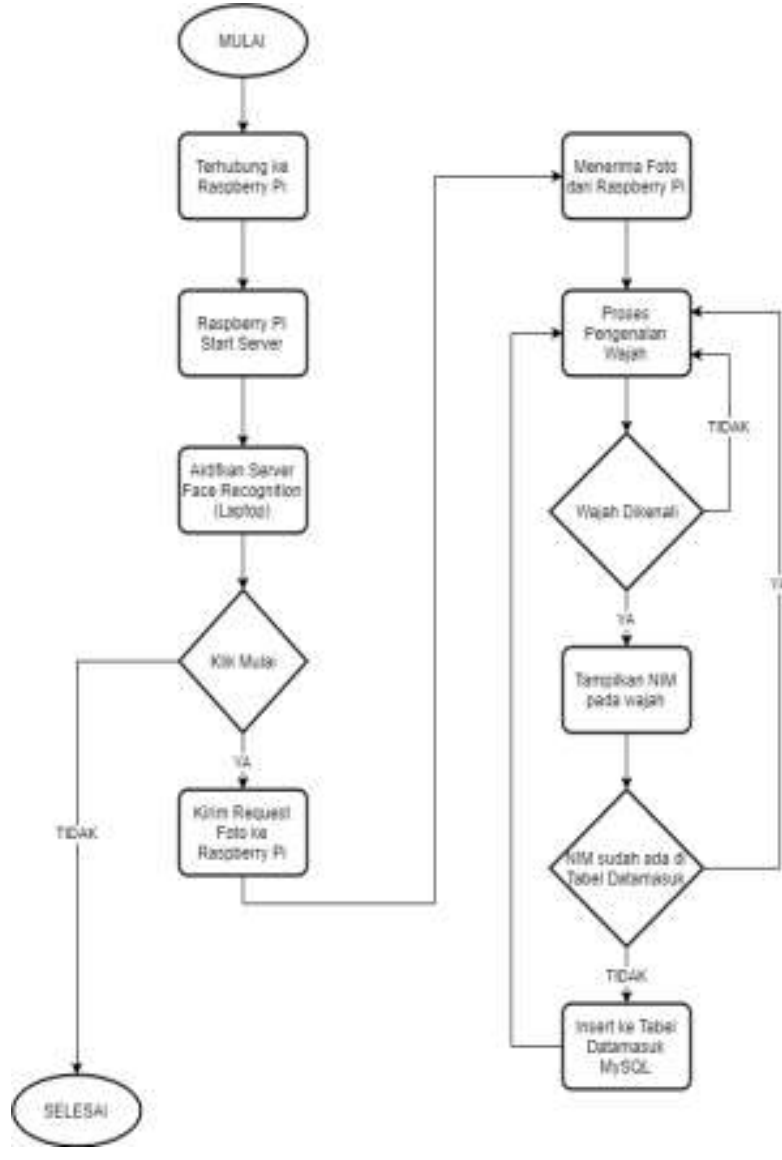

Gambar 3 Alir diagram server Python.

Pembuatan sistem menggunakan perangkatperangkat keras maupun perangkat-perangkat lunak untuk mendukung terselesaikannya pembuatan sistem. Berikut ini dijelaskan perangkat- perangkat yang digunakan pada saat pembuatan.

Dalam memenuhi perancangan dan pengimplementasian sistem ini dibutuhkan perangkat keras yang akan digunakan agar berjalannya sistem ini. Perangkat keras yang digunakan adalah sebagai berikut:

Tabel 1 Kebutuhan perangkat keras.

\begin{tabular}{|l|l|l|}
\hline NO & $\begin{array}{l}\text { NAMA } \\
\text { PERANGKAT } \\
\text { KERAS }\end{array}$ & FUNGSI \\
\hline 1. & $\begin{array}{l}\text { Laptop Intel Core i3 } \\
\text { CPU @ 2.27GHz }\end{array}$ & $\begin{array}{l}\text { Sebagai remote } \\
\text { raspberry dan } \\
\text { transimisi data }\end{array}$ \\
\hline 2. & $\begin{array}{l}\text { Raspberry Pi 3 Type } \\
\text { B }\end{array}$ & $\begin{array}{l}\text { Sebagai kontrol } \\
\text { sistem }\end{array}$ \\
\hline 3. & $\begin{array}{l}\text { Raspberry } \\
\text { Camera V1.3 Pi }\end{array}$ & Sebagai kamera \\
\hline
\end{tabular}


RESISTOR (Elektronika Kendali Telekomunikasi Tenaga Listrik Komputer) Vol. 3 No. 1 e-ISSN : 2621-9700, p-ISSN : 2654-2684

\begin{tabular}{|l|l|l|}
\hline 4. & Power Supply & $\begin{array}{l}\text { Sebagai sumber } \\
\text { tegangan } \\
\text { raspberry }\end{array}$ \\
\hline
\end{tabular}

Dalam memenuhi kebutuhan perancangan dan peelitian penelitian ini dibutuhkan perangkat lunak yang akan digunakan. Adapun perangkat lunak yang akan digunakan sebagai berikut :

Tabel 2 Kebutuhan perangkat lunak.

\begin{tabular}{|c|c|c|}
\hline NO & $\begin{array}{l}\text { NAMA } \\
\text { PERANGKAT } \\
\text { LUNAK }\end{array}$ & FUNGSI \\
\hline 1. & Windows 10 pro & $\begin{array}{ll}\begin{array}{l}\text { Sebagai } \\
\text { operasi }\end{array} & \text { sistem }\end{array}$ \\
\hline 2. & Python 3.6.8 & $\begin{array}{l}\text { Sebagai bahasa } \\
\text { pemrograman }\end{array}$ \\
\hline 3. & $\begin{array}{ll}\text { VNC } & \text { Viewer } \\
6.9 .1115 & \end{array}$ & $\begin{array}{l}\text { Sebagai koneksi } \\
\text { antara laptop dan } \\
\text { raspberry }\end{array}$ \\
\hline 4. & Xampp v3.2.4 & $\begin{array}{l}\text { Sebagai kontrol } \\
\text { server untuk } \\
\text { menjalankan } \\
\text { MySQL }\end{array}$ \\
\hline 5. & Notepad & $\begin{array}{l}\text { Untuk membuat } \\
\text { code program }\end{array}$ \\
\hline
\end{tabular}

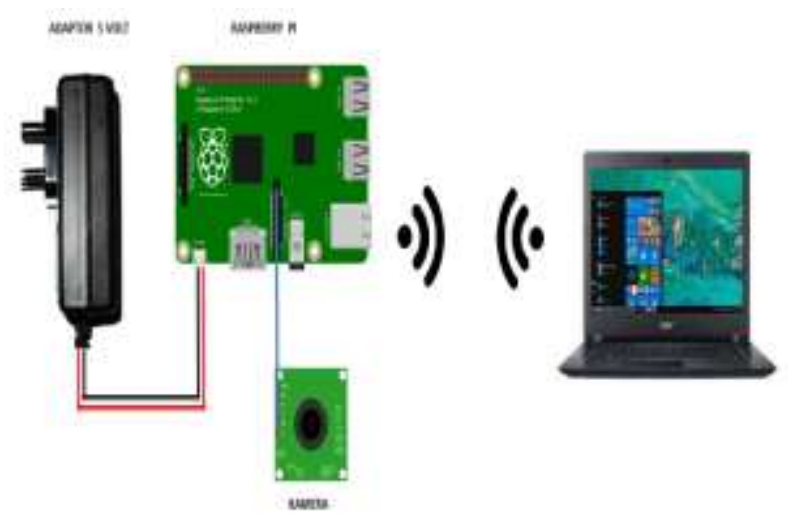

Gambar 4 Rangkaian sistem.

Pada diagram blok tersebut dijelaskan bahwa rasberry pi sebagai kontrol utama. Dimana laptop hanya mengendalikan server php dan server phyton melalui hotspot. Pastikan hotspot tetap tersambung sehingga semua sistem dikendalikan oleh laptop. Laptop berisi server pendukung seperti server PHP dan server python. Server PHP sebagai database untuk penyimpanan data dan kontrol server xampp untuk menghandle web. Dan server python sebagai server untuk menjalankan sever face recognititon. Dimana raspberry kamera sebagai kontrol pendukung server face recognition untuk mengenali wajah mahasiswa. Raspberry pi dihubungkan ke power supply dimana power supply sebagai penyuplai arus listrik untuk raspberry pi.

Database pada peracangan ini digunakan untuk menyimpan data berupa nim mahasiswa dan jam masuk. Database dibuat dua tabel didalamnya yaitu, tabel data mahasiswa dan tabel data masuk. Tabel data mahasiswa adalah tabel yang berisi biodata mahasiswa seperti: id, nim mahasiswa dan nama mahasiswa. Tabel data masuk adalah tabel yang berisi nim masuk mahasiswa seperti: nim mahasiswa, dan jam masuk.

Berikut dijelaskan pada tabel :

Tabel 3 Struktur data mahasiswa.

\begin{tabular}{|l|l|l|}
\hline \multicolumn{1}{|c|}{ Name } & \multicolumn{1}{c|}{ Type } & \multicolumn{1}{c|}{ Collation } \\
\hline Id & int(100) & \\
\hline Nim & varchar(100) & utf8mb4_general_ci \\
\hline Nama & varchar(100) & utf8mb4_general_ci \\
\hline
\end{tabular}

Tabel 4 Struktur data masuk.

\begin{tabular}{|l|l|c|}
\hline \multicolumn{1}{|c|}{ Name } & \multicolumn{1}{c|}{ Type } & Collation \\
\hline Nim & char(100) & utf8mb4_general_ci \\
\hline $\begin{array}{l}\text { jam } \\
\text { masuk }\end{array}$ & Timestamp & \\
\hline
\end{tabular}

\section{PENGUJIAN DAN ANALISA}

Setelah selesai merancang sistem pengenalan wajah ini, selanjutnya dilakukan uji coba untuk mengetahui akurasi dan ketepatan sistem dalam mengenali wajah mahasiswa. Dalam uji coba ini dilakukan dalam beberapa kondisi yang berbeda. Kondisi tersebut yaitu intensitas cahaya yang berbeda, jarak yang mahasiswa dengan raspberry kamera dan pose wajah mahasiswa.

Dalam perancangan ini didapat beberapa pencahayaan yang dapat mendeteksi wajah mahasiswa. Ada beberapa tingkat pencahayaan dalam mengenali wajah mahasiswa. Sumber cahaya yang digunakan menggunakan lampu 15 watt dan dibantu senter hp dengan jarak $60 \mathrm{~cm}$. Berikut data 
RESISTOR (Elektronika Kendali Telekomunikasi Tenaga Listrik Komputer) Vol. 3 No. 1 e-ISSN : 2621-9700, p-ISSN : 2654-2684

uji coba intensitas cahaya yang dapat mengenali wajah mahasiswa :

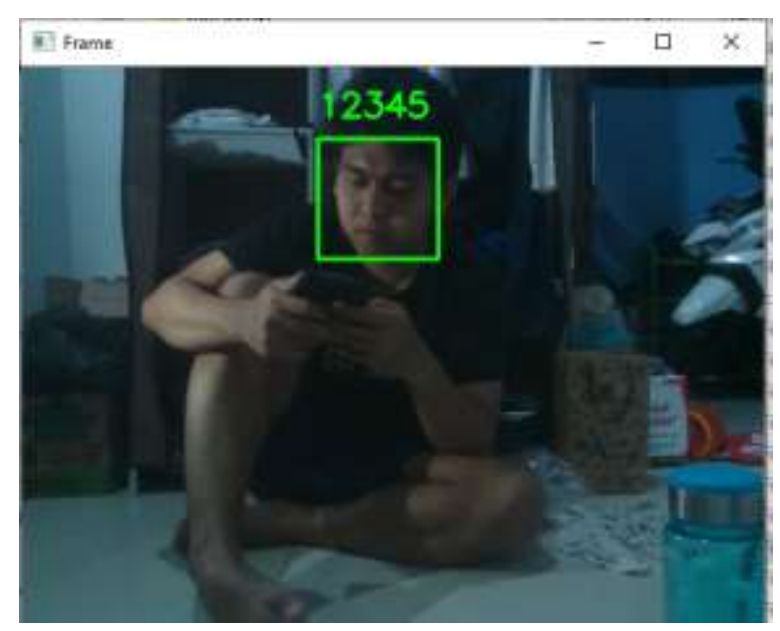

Gambar 5 Pencahayaan 300 lux jarak 1 meter.

Penelitian penelitian ini juga melakukan akurasi jarak mahasiswa dengan raspberry kamera. Dimana analisa jarak ini untuk mengetahui seberapa jauh jarak mahasiswa dengan rapsberry kamera dalam mengenali wajah mahasiswa. Untuk dilakukan beberapa uji coba sebagai berikut :

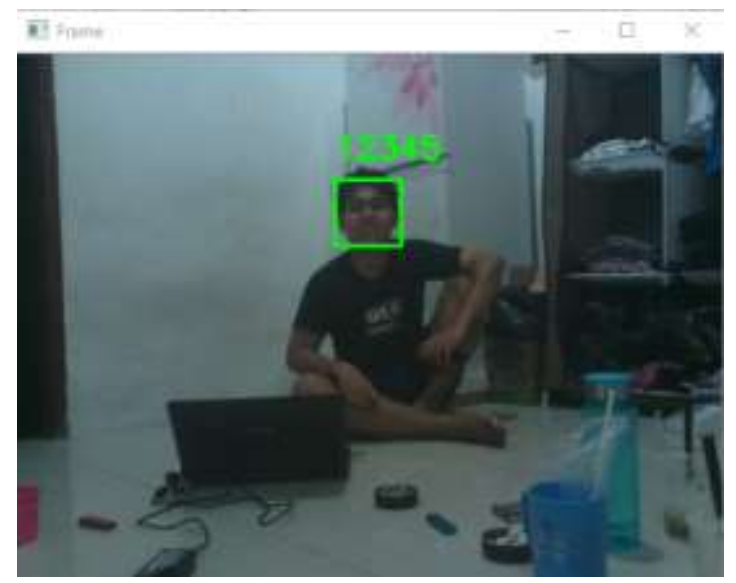

Gambar 6 Jarak 2 meter dengan pencahayaan 200 lux.

Penelitian penelitian ini juga menganalisa wajah mahasiswa dalam beberapa pose miring yang dapat dikenali dan terdeteksi. Pose miring ini dapat menjadi pertimbangan apabila mahasiswa sedang melakukan aktivitas. Jadi tidak selalu menghadap tegak lurus ke depan. Berikut beberapa uji coba pose wajah mahasiswa :

Tabel 5 Pose wajah mahasiswa.

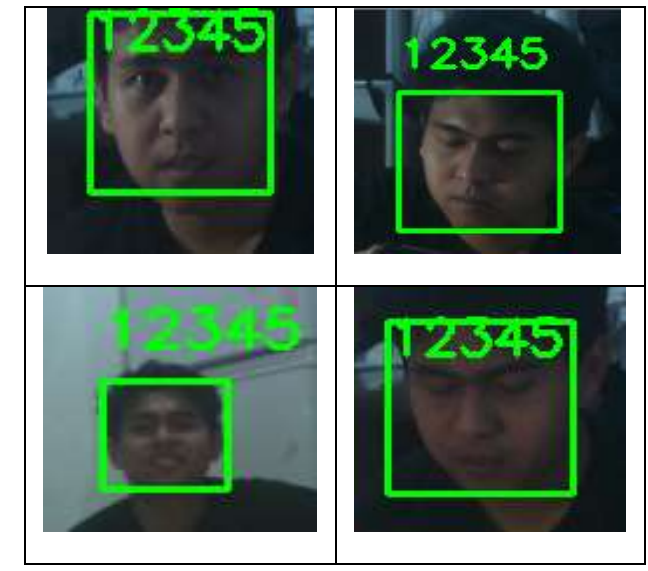

\section{KESIMPULAN}

Berdasarkan hasil uji coba dan pembahasan pada bab sebelumnya, maka dapat disimpulkan sebagai berikut :

1. Metode Histogram of Oriented Gradients dapat diimplementasikan ke dalam sistem dengan baik menggunakan bahasa pemrograman pyhton, sehingga sistem dapat mendeteksi dan mengenali wajah mahasiswa.

2. Dapat dianalisa dari hasil uji coba bahwa tingkat pencahayaan minimum 80 lux dan pencahayaan maksimum 300 lux. Kemudian jarak mahasiswa dengan raspberry kamera maksimum 2 meter dan jarak minimum $10 \mathrm{~cm}$. Selanjutnya posepose wajah yang dapat terdeteksi harus masih terlihat seluruh wajah. Dalam penelitian ini didapat tingkat akurasi intensitas cahaya, jarak dan pose yang dapat terdeteksi. Apabila ada yang tidak sesuai dari hasil uji coba tersebut, maka wajah tidak terdeteksi dan mengenali wajah mahasiswa.

3. Foto yang digunakan untuk database minimal 5 foto, 4 foto dengan pose 45 derajat menghadap atas, bawah, kiri dan kanan ke kamera, 1 foto dengan pose menghadap tegak lurus ke kamera. Foto yang disimpan database harus terang dan terlihat jelas, dikarenakan apabila ada kemiripan wajah tidak salah masuk data mahasiswannya.

4. Kapasitas database 1 mahasiswa minimal 5 foto, 1 foto didapat $100 \mathrm{~KB}$ jika 5 foto menjadi 500 $\mathrm{KB}$ jadi 1 mahasiswa mempunyai kapasistas database $500 \mathrm{~KB}$. Kapasitas kemampuan alat hanya 5 mahasiswa didapat dengan jumlah 2500 $\mathrm{KB}$ atau sama dengan 2,5 MB

5. Penyesuaian resolusi kamera yang digunakan untuk database mahasiswa dengan kamera yang digunakan alat ini.

6. Ruangan pada saat alat ini berjalan harus sesuai tingkat pencahayaannya agar wajah mudah terdeteksi.

\section{DAFTAR PUSTAKA}


RESISTOR (Elektronika Kendali Telekomunikasi Tenaga Listrik Komputer) Vol. 3 No. 1 e-ISSN : 2621-9700, p-ISSN : 2654-2684

[1] S. Sepritahara, "SISTEM PENGENALAN WAJAH (FACE RECOGNITION) MENGGUNAKAN METODE HIDDEN MARKOV MODEL (HMM)," Universitas Indonesia, Depok, 2012.

[2] B. Purnama and S. Si, "Identifikasi Telapak Tangan Menggunakan 2DPCA plus PCA dan K- Nearest Neighbour," Seminar Nasional Aplikasi Teknologi Informasi 2013, pp. 1-6, 2013.

[3] M. A. Siddiq, I. Santoso, and A. A. Zahra, "IDENTIFIKASI WAJAH MANUSIA DENGAN ANALISIS KOMPONEN BEBAS," Transient: Jurnal Ilmiah Teknik Elektro, vol. 6, no. 2, pp. 254-259, 2017.

[4] F. Fandiansyah, J. Y. Sari, and I. P. Ningrum, "Pengenalan Wajah Menggunakan Metode Linear Discriminant Analysis dan k Nearest Neighbor," Ultimatics: Jurnal Teknik Informatika, vol. 9, no. 1, pp. 1-9, 2017.

[5] Y. X. Chu, X. G. Liu, and C. H. Gao, "Multiscale models on time series of silicon content in blast furnace hot metal based on Hilbert-Huang transform," Proceedings of the 2011 Chinese Control and Decision Conference, CCDC 2011, pp. 842-847, 2011, doi: 10.1109/CCDC.2011.5968300.

[6] K. Suryadi and S. Sikumbang, "Human Detection Menggunakan Metode Histogram Of Oriented Gradients (HOG) Berbasis OPEN_CV," Jurnal Pendidikan Teknik Elektro, vol. 4, no. 2, pp. 639-645, 2015.

[7] C. Yan-Xu, L. Xiang-Guan, and G. ChuanHou, "Multiscale models on time series of silicon content in blast furnace hot metal based on Hilbert-Huang transform," in 2011 Chinese Control and Decision Conference (CCDC), 2011, pp. 842-847.

[8] D. Suprianto and R. N. Hasanah, "Sistem Pengenalan Wajah Secara Real-Time dengan Adaboost, Eigenface PCA \& MySQL," Jurnal Eeccis, vol. 7, no. 2, pp. 179-184, 2014.

[9] C. Suhery and I. Ruslianto, "Identifikasi Wajah Manusia untuk Sistem Monitoring Kehadiran Perkuliahan menggunakan Ekstraksi Fitur Principal Component Analysis (PCA)," Jurnal Edukasi dan Penelitian Informatika (JEPIN), vol. 3, no. 1, pp. 9-15, 2017.
[10] B. T. Atmaja, A. S. Aisyah, and D. Arifianto, "Pemisahan Banyak Sumber Suara Mesin Menggunakan Independent Component Analysis (Ica) Untuk Deteksi Kerusakan," Jurnal Ilmu Komputer dan Informasi, vol. 3, no. 1 , pp. 30-37, 2012.

[11] S. Cahyani, R. Wiryasaputra, and R. Gustriansyah, "Identifikasi Huruf Kapital Tulisan Tangan Menggunakan Linear Discriminant Analysis dan Euclidean Distance," JSINBIS (Jurnal Sistem Informasi Bisnis), vol. 8, no. 1, pp. 57-67.

[12] H. Isyanto, A. Solikhin, and W. Ibrahim, "Perancangan dan Implementasi Security System pada Sepeda Motor Menggunakan RFID Sensor Berbasis Raspberry Pi," RESISTOR (elektRonika kEndali telekomunikaSI tenaga liSTrik kOmputeR), vol. 2, no. 1, pp. 29-38, 2019.

[13] H. Muchtar and R. Sumanjaya, "Control Switch Otomatis pada Tegangan Energi Alternatif dan Tegangan Sumber PLN Menggunakan Raspberry Pi," RESISTOR (elektRonika kEndali telekomunikaSI tenaga liSTrik kOmputeR), vol. 1, no. 2, 2018.

[14] H. Muchtar, M. D. Nasirudin, and R. Adhitama, "Perancangan Sistem Kontrol dan Monitoring Beban Listrik Menggunakan Raspberry Berbasis Ip," RESISTOR (elektRonika kEndali telekomunikaSI tenaga liSTrik kOmputeR), vol. 1, no. 1, 2018.

[15] S. Bahri and K. Fikriyah, "PROTOTYPE MONITORING PENGGUNAAN DAN KUALITAS AIR BERBASIS WEB MENGGUNAKAN RASPBERRY PI," eLEKTUM, vol. 15 , no. 2, 2018.

[16] A. N. Syahrudin and T. Kurniawan, "INPUT DAN OUTPUT PADA BAHASA PEMROGRAMAN PYTHON," Jurnal Dasar Pemograman Python STMIK, 2018.

[17] M. Tandean, S. Solikin, and R. Hendriyanto, "APLIKASI MONITORING RUNTIME SERVER DAN IMPLEMENTASI VNC REMOTE SERVER BERBASIS ANDROID."

[18] R. Sovia and J. Febio, "Membangun Aplikasi E-Library Menggunakan Html, Php Script, Dan Mysql Database," Jurnal Processor, vol. 6, no. 2, 2017.

[19] J. Yang, L. Liu, T. Jiang, and Y. Fan, "A modified Gabor filter design method for fingerprint image enhancement," Pattern 
RESISTOR (Elektronika Kendali Telekomunikasi Tenaga Listrik Komputer) Vol. 3 No. 1 e-ISSN : 2621-9700, p-ISSN : 2654-2684

Recognition Letters, vol. 24, no. 12, pp. 1805-1817, 2003.

[20] kbbi kbbi, https://kbbi.web.id/wajah, 27-

Dec-2019. [Online]. Available:

https://kbbi.web.id/wajah. 